\title{
Morphology and ultrastructure of the adult ovarian cycle in Mithracidae (Crustacea, Decapoda, Brachyura, Majoidea)
}

\author{
Michelle Mollemberg ${ }^{1}$, Fernando José Zara ${ }^{2}$ and William Santana ${ }^{1 *}$ (i)
}

\begin{abstract}
The ultrastructure of the ovary during development and yolk production is poorly known in Brachyura and Majoidea in particular. Here, we describe the histology, histochemistry and ultrastructure of the adult ovarian cycle in four Mithracidae species from three different genera: Mithrax hispidus, Mithrax tortugae, Mithraculus forceps and Omalacantha bicornuta. All species showed a similar pattern of ovarian development and vitellogenesis. Macroscopically, we detected three stages of ovarian development: rudimentary (RUD), developing (DE) and mature (MAT); however, in histological and ultrastructural analyses, we identified four stages of development. The oocytes of the RUD stage, during endogenous vitellogenesis, have basophilic cytoplasm filled with dilated rough endoplasmic reticulum. The reticulum lumen showed many granular to electron-dense materials among the different stages of development. The Golgi complexes were only observed in the RUD stage and are responsible for releasing vesicles that merge to the endogenous or immature yolk vesicles. At the early DE stage, the oolemma showed many coated and endocytic vesicles at the cortex. The endocytic vesicles merge with the endogenous yolk to form the exogenous or mature yolk vesicles, always surrounded by a membrane, characterizing exogenous vitellogenesis. The exogenous yolk vesicles comprise glycoproteins, showing only neutral polysaccharides. At the late DE stage, endocytosis still occurs, but the amount of endogenous yolk decreases while the exogenous yolk increases. The late DE stage is characterized by the beginning of chorion production among the microvilli. The MAT stage is similar to the late DE, but the endogenous yolk is restricted to a few cytoplasmic areas, the ooplasma is filled with exogenous yolk, and the oolemma has very few coated vesicles. In the MAT stage, the chorion is fully formed and shows two electron-dense layers. The ovarian development of the species studied has many similarities with the very little known Majoidea in terms of the composition, arrangement and increment of the yolk vesicles during oocyte maturation. The main differences are in the vitellogenesis process, where immature yolk formation occurs without the direct participation of the mitochondria but with the participation of the rough endoplasmic reticulum in the endogenous phase.
\end{abstract}

Keywords: Histology, Mithrax, Mithraculus, Omalacantha, Transmission electron microscopy

\section{Background}

Studies on reproductive cycles and ovarian development can provide important information for the establishment of guidelines applicable to the management of natural stocks in decapod crustaceans [1]. Similarly, the structural and functional comprehension of the reproductive system

\footnotetext{
*Correspondence: willsantana@gmail.com

1 Universidade do Sagrado Coração - USC, Pró-Reitoria de Pesquisa e PósGraduação, Rua Irmã Arminda, 10-50, Jd. Brazil, Bauru, SP 17011-160, Brazil Full list of author information is available at the end of the article
}

is fundamental to understanding the fertilization mechanisms and behavioral and anatomical evolution of mating in Brachyura [2, 3]. In females, the evaluation of physiological maturity encompasses the study of these functional and structural characteristics. Ovarian development until ovulation is commonly assessed by macroscopic analyses using the color and proportion of the gonads in the cephalothorax for several brachyuran groups, including portunids, aethrids and majoids [4-6]. Although macroscopic analyses are common, detailed information about ovarian 
development ultrastructure are rare compared with the great biodiversity of brachyurans [7].

Majoidea is the largest brachyuran superfamily, with 910 valid species distributed in six families [8]. It is composed mostly of small and medium-sized crabs, with several species subject to commercial exploitation for both consumption (e.g., Maja brachydactyla Balss, 1922) and aquarium hobby (e.g., Mithraculus forceps A Milne-Edwards,1875) [9-11]. Along the Brazilian coast, Majoidea is represented by approximately 90 species distributed in 45 genera, including the Mithracidae studied here: Mithrax hispidus (Herbst, 1790), Mithrax tortugae (Rathbun, 1920), Mithraculus forceps and Omalacantha bicornuta (Latreille, 1825), which can be easily found in the intertidal and sublittoral zones [12].

Based on macroscopic and histological characteristics, ovarian development in Majoidea can be divided into four stages, two corresponding to the immature and two to the mature phases $[6,13,14]$. These four stages are characterized by the presence of lipid and neutral polysaccharides and the absence of acid polysaccharides in all stages of the development [14]. However, similar to most brachyuran crabs, detailed information about ovarian development in Majoidea is scarce and restricted to Chionoecetes opilio (Fabricius, 1788) and Hyas coarctatus Leach, 1816 [14] and Maja squinado (Herbst, 1788) [13], and the ultrastructure of ovary during development and vitellogenesis was only studied in Libinia emarginatta Leach, 1815 [15] and Ma. brachydactyla [16]. In both species, the endogenous and exogenous vitellogenesis depicts different patterns of yolk formation, making any comparative analysis difficult. In addition, nothing is known about the histology and ultrastructure of adult ovarian cycle of any Mithracidae species until now.

Here, we describe the ovarian development and yolk production for four species from three different genera of Mithracidae to verify the possible differences in the yolk formation and composition among the family.

\section{Methods}

Female crabs of Mithrax hispidus, M. tortugae, Mithraculus forceps and Omalacantha bicornuta were manually collected in Ubatuba and Laje the Santos, São Paulo state, Brazil during SCUBA and free diving sessions. After sampling, the crabs were kept alive in aerated containers and were transported to the laboratory where the experiments were performed. The specimens were identified following the appropriate literature $[12,17,18]$.

Females were discriminated according to the developmental stage (i.e., juvenile with a narrower abdomen attached to the sterno-abdominal cavity or adult with detached and rounded abdomen) and were anesthetized by thermal shock of $-20{ }^{\circ} \mathrm{C}$ for $15 \mathrm{~min}$ [19]. The dorsal carapace was removed using a Dremel@ rotary tool, and the ovarian maturation stages were classified macroscopically according to the color, size and relative proportion of the gonads to the hepatopancreas following the criteria used by Costa and Negreiros-Fransozo [4] and Zara et al. [7].

For light microscopy, ovary samples of approximately $3 \mathrm{~cm}^{3}$ from the anterior region of the cephalothorax (right side) were fixed in 4\% paraformaldehyde prepared with water from the collection site and $0.2 \mathrm{M}$ sodium phosphate buffer ( $\mathrm{pH} 7.2)$ for $24 \mathrm{~h}$. After fixation, the material was dehydrated in a progressive series of ethanol (70-95\%), embedded and included in methacrylate resin (Historesin ${ }^{\circledR}$-Leica) using routine procedures. Serial sections of $5-8 \mu \mathrm{m}$ were obtained in a rotary microtome, and the slides were stained with hematoxylin and eosin for traditional histology description [20], avoiding xylene and ethanol baths [21]. To demonstrate the presence of proteins, we used mercuric-bromophenol blue [22, 23] and xylidine ponceau [24]. For acid and neutral polysaccharides, we used Alcian blue and Periodic Acid Schiff (PAS), respectively [20].

For transmission electron microscopy (TEM), samples of $1-2 \mathrm{~mm}^{3}$ of the different ovarian stages from the anterior margin of the cephalothorax (left side) were fixed in $3 \%$ glutaraldehyde in $0.1 \mathrm{M}$ sodium cacodylate buffer ( $\mathrm{pH} 7.2)$ for $4 \mathrm{~h}$ at $4{ }^{\circ} \mathrm{C}$ and were post-fixed in $1 \%$ osmium tetroxide in the same buffer for $2 \mathrm{~h}$. The samples were "En Bloc" stained overnight with $1 \%$ aqueous uranyl acetate, were subsequently dehydrated in an ascending series of acetone $(70-100 \%)$ and then were embedded in Epon-Araldite resin. Thin and ultrathin sections were cut using an ultramicrotome Leica UC7. The Ultrathin sections were collected using copper grids and stained with $2 \%$ uranyl acetate in water and $0.2 \%$ lead citrate in $0.1 \mathrm{M}$ $\mathrm{NaOH}$. The grids were examined and photographed using Jeol J1010 transmission electron microscopy with an 80-Kv electron beam.

For oocyte measurement, we used the Leica IM50 software to measure the longest diameter of 30 whole oocytes with visible nuclei and nucleoli in each stage of development with a $10 \times$ objective. The normality of the oocyte diameter was evaluated by the Shapiro-Wilk test, and the average and standard deviation were compared using the Dunn test $(p<0.05)$ when the Kruskal-Wallis test indicated differences among the ovarian stages. For Omalacantha bicornuta, we did not have a sufficient number of oocytes at all developmental stages to include the species in the statistical analyses.

\section{Results}

All species analyzed here show the same pattern of ovarian development. Thus, according to the macroscopic characterization of the ovaries, three stages of 
development were established for these species: rudimentary-RUD, developing-DE and mature-MAT.

In the RUD stage, the ovary presented a central germinal zone composed of oogonia and oocytes arranged at the periphery. The whole ovary is surrounded by a thick layer of dense connective tissue (Fig. 1a). The oogonia have a high nuclear proportion relative to the size of the cell, the nuclei have chromosomes in meiotic prophase and the cytoplasm is basophilic and less intense than the chromosomes (Fig. 1b). Follicular cells surround the oocytes, which are flattened, with acidophilic cytoplasm and elliptic nuclei constituting a simple squamous epithelium (Fig. 1a, c). The oocytes have large nuclei with diffuse chromatin, large nucleoli and basophilic cytoplasm (Fig. 1d, e). From the germinal zone to the periphery, there is an increase in the size of the oocytes (Fig. 1f). The rudimentary oocytes furthest from the germinal zone have lucid vesicles and vesicles that contain acidophilic material forming endogenous yolk (Fig. 1d-f). The endogenous yolk comprises glycoproteins due to its strong reactivity for proteins and neutral polysaccharides (Fig. 1g, h) and the absence of acid polysaccharides (Fig. 1i). The cytoplasm is also reactive for proteins and neutral polysaccharides (Fig. 1g, h).

According to the ultrastructural analyses, the ovary is surrounded by connective tissue composed of several fibroblasts with elliptical nuclei and heterochromatin accumulated next to the nuclear envelope preferably and collagen fibers arranged irregularly between the fibroblasts in different directions (Fig. 2a, b). The oogonia have numerous mitochondria and polyribosomes in the cytoplasm. The nuclei are found in different stages of meiosis, and in several of them, we can observe the pairing of the chromosomes, as identified by the presence of the synaptonemic complex (Fig. 2c, d). The follicular cells have electron-dense basal lamina and cytoplasm filled with mitochondria, rough endoplasmic reticulum (RER) and free polyribosomes. The nuclei are elliptical, containing several blocks of heterochromatin, which are commonly associated with the nuclear envelope. At this early stage of ovarian development, the oocyte microvilli and follicular cells are weakly developed (Fig. 2e).

The RUD oocytes closest to the germinal zones have cytoplasm with many polyribosomes and mitochondria. The perinuclear region shows many electron-dense ribosome-like granules or nuage. The large nucleus shows heterochromatin granules dispersed throughout the nucleoplasm and a rounded nucleolus (Fig. 2f-h). The most peripheral oocytes have a much dilated RER with granular material of different electron densities in its interior. Among the RER, we observed several mitochondria (Fig. 2i). In the oocyte cortex, portions of the RER are composed of the electron-dense spherical luminal and compact material characterizing the endogenous yolk vesicles, which marks previtellogenesis or endogenous vitellogenesis (Fig. 2i-k). In the middle of the highly dilated RER, many typical Golgi complexes can be observed (Fig. 2j, l). The Golgi complex clearly receives materials from the endoplasmic reticulum through the transitional element vesicles that are electron-lucid on the cis face and release vesicles with finely electron-dense material on the trans face, which are similar to the material found in the dilated RER (Fig. 2l).

Two cellular patterns related to the oocyte development were identified during the DE stage. This stage was divided in initial and final DE, the latter corresponding to the intermediate stage (INT). However, this division could not be observed macroscopically and the INT stage was only used in histological and ultrastructural descriptions. In the beginning of the DE stage, the oocyte cortex shows no evidence of the chorion, and the oocytes are completely surrounded by follicular cells maintaining the same size from the previous stage (i.e., RUD) (Fig. 3a-c). This stage is characterized by the presence of mature yolk vesicles in the cytoplasm preferably distributed from the oocyte cortex to the cell center. The nucleus is central and has a smaller volume in relation to the cytoplasm. The mature yolk vesicles are less common in the perinuclear space, and numerous cytoplasmic vesicles are found in this region (Fig. 3a, b). The cytoplasm among the yolk vesicles shows lucent vesicles unstained to all techniques used (Fig. 3b, d-f). The cytoplasm is reactive for neutral polysaccharides, indicating the presence of glycogen (Fig. 3f). The yolk vesicles are glycoprotein structures with basic amino acids and neutral polysaccharides intensely reactive to xylidine and PAS (Fig. $3 \mathrm{~d}-\mathrm{f}$ ). The most developed oocytes of the DE stage have the perinuclear space filled with mature yolk vesicles, with easily visualized rounded nuclei in the central region (Fig. 3g, i). The oocyte cortex shows a thin chorion (Fig. 3h). The histochemical composition of the mature yolk vesicles has the same strong reactivity for proteins and neutral polysaccharides as the early DE stage (Fig. 3j, k). Such vesicles do not present acid polysaccharides in its composition (Fig. 31).

In TEM, the oocyte cortex of the DE early stages does not have a chorion. In this phase, two types of cytoplasmic vesicles are visible: the first is smaller, with electrondense luminal material, which varies from granular to fibrous aspects, called immature or endogenous yolk vesicles (Y1); the second type of vesicle is larger, and its content is electron-dense, called mature or exogenous yolk vesicles (Y2) (Fig. 4a, b). Y1 can occur throughout the cytoplasm but are particularly abundant in the perinuclear region. Among the vesicles, we can observe several lipid droplets of different sizes (Fig. 4b) that are observed 

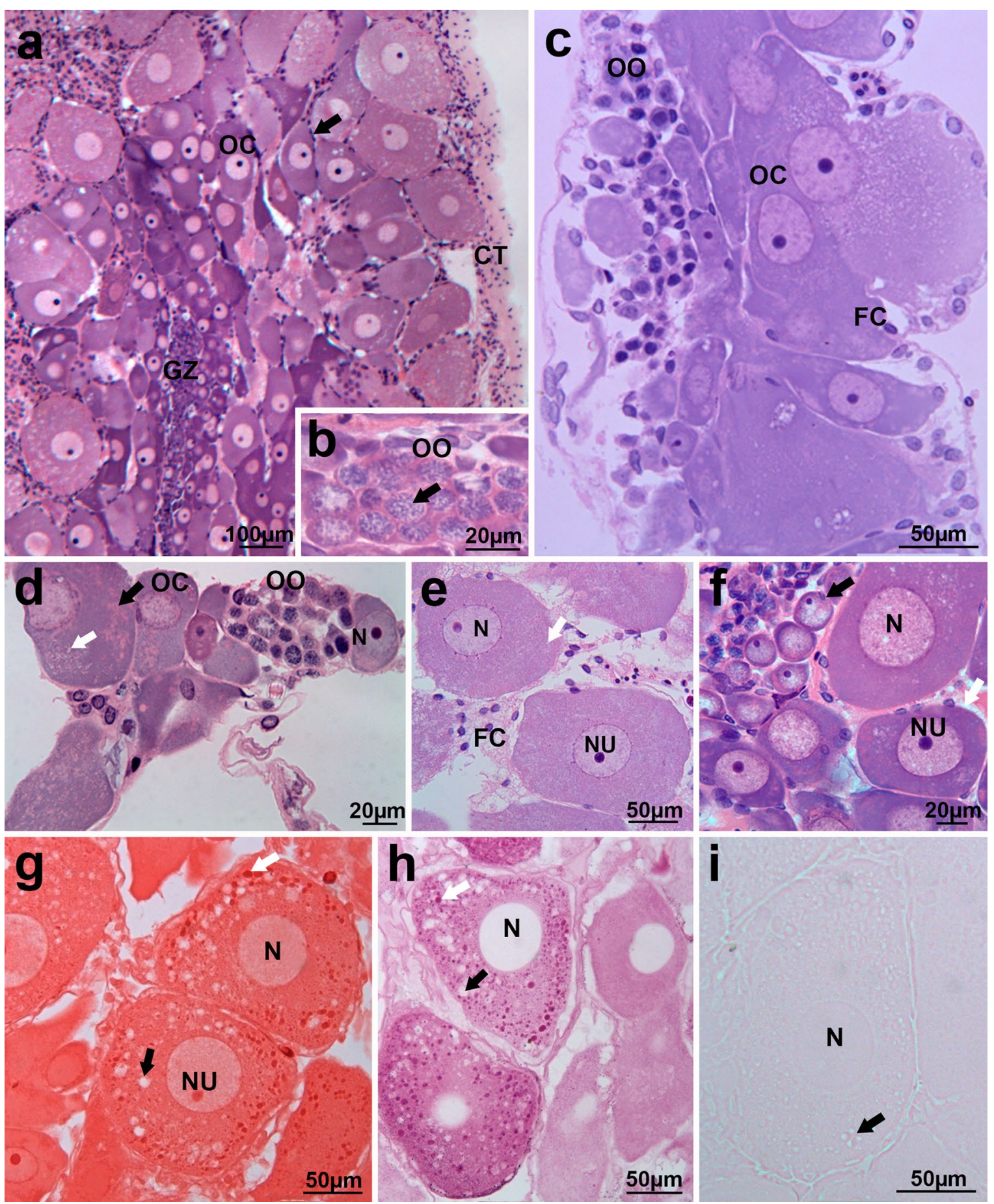

Fig. 1 Ovary at the RUD stage under light microscopy; a-f sections stained with hematoxylin and eosin (HE); $\mathbf{g} x y l i d i n e$ ponceau stain; $\mathbf{h}$ PAS stain; i Alcian blue stain; a, b Mithrax tortugae (Rathbun, 1920). a Ovarian structure enveloped by a thick layer of connective tissue. Note the oocytes surrounded by follicular cells (black arrow) arranged in the periphery with a central germinal zone; b oogonia with nucleus occupying a large part of the cells and basophilic cytoplasm, nuclei with meiotic prophase (black arrow); c Mithraculus forceps A. Milne-Edwards, 1875, proliferation of oogonia and presence of follicular cells around the oocytes; d, e Omalacantha bicornuta (Latreille, 1825) and Mithraculus forceps, presence of lucid vesicles (white arrows) and vesicles with acidophilic material (black arrow) in the cytoplasm of oocytes; $\mathbf{f}$ Mithrax hispidus (Herbst, 1790), increase in oocyte size from the germinal zone (black arrow) towards the periphery (white arrow); $\mathbf{g}$, h Mithrax tortugae andMithraculus forceps, cytoplasm and endogenous yolk vesicles with positive reactivity for proteins and neutral polysaccharides; i Mithrax hispidus, cytoplasm and endogenous yolk vesicles with the absence of acid polysaccharides. Note the presence of endogenous yolk vesicles (white arrows) and lucid vesicles (black arrows) in the oocytes. CT connective tissue, FC follicular cell, GZ germinal zone, N nucleus, NU nucleolus; OC oocyte, OO Oogonia 

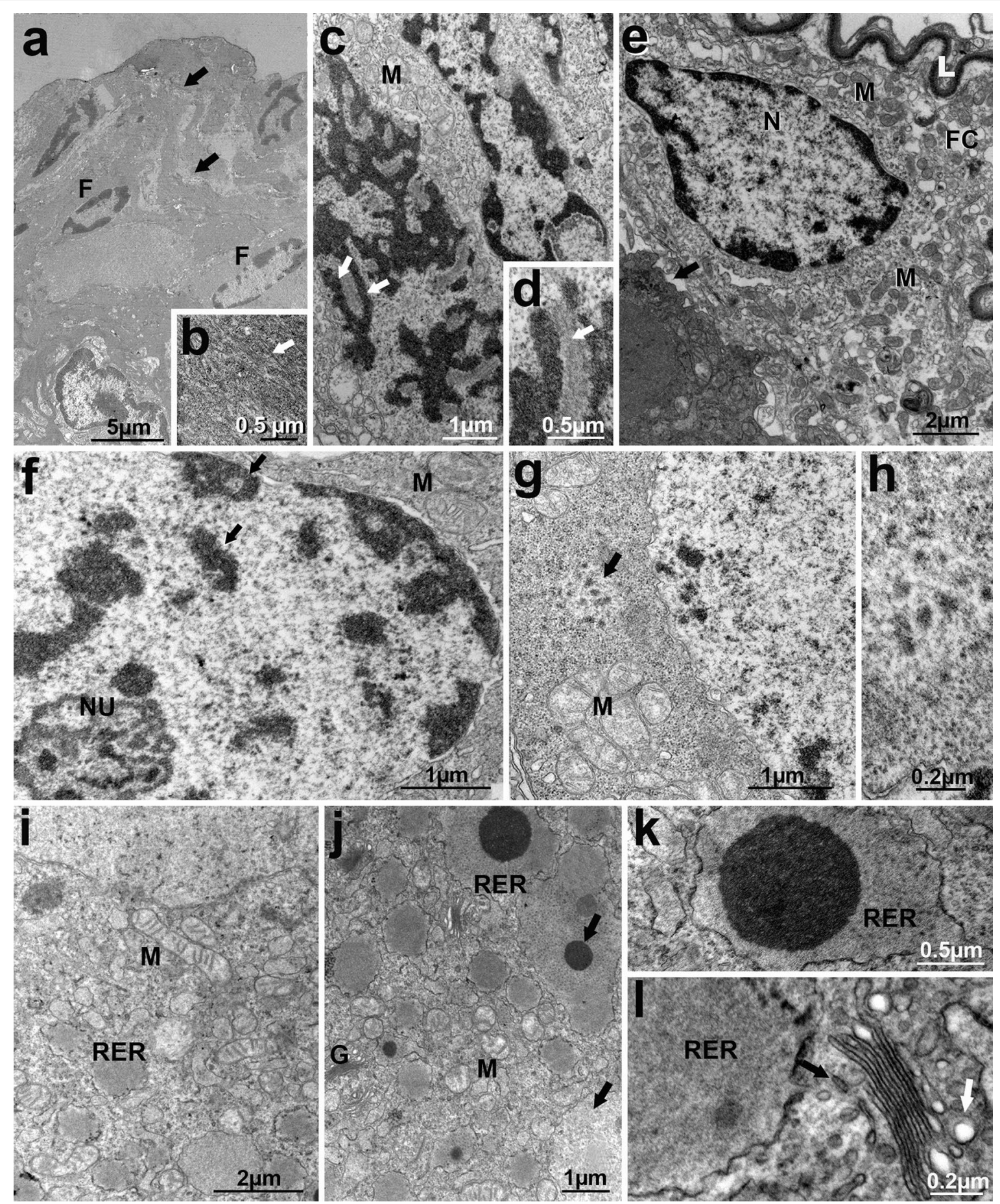

Fig. 2 Transmission electron microscopy of the ovary at the RUD stage; a connective tissue showing several fibroblasts with elliptic nuclei and heterochromatin accumulated to the nuclear envelope; b collagen fibers among fibroblasts (white arrow); c oogonia with mitochondria and polyribosomes in the cytoplasm and nuclei at the different meiosis stages. Note the pairing of the chromosomes (white arrows); $\mathbf{d}$ synaptonemic complex (white arrow); e follicular cell with elliptical nucleus, electron-dense basal lamina and cytoplasm filled by mitochondria. Oocyte and follicular cell microvilli poorly developed (black arrow); f oocyte with large nucleus, with heterochromatin granules dispersed throughout the nucleoplasm (black arrows) and rounded nucleolus; $\mathbf{g}$ cytoplasm with many polyribosomes and mitochondria. Note the electron-dense granules in the perinuclear region (black arrow); $\mathbf{h}$ detail of the electron-dense granules or nuage; $\mathbf{i}-\mathbf{k}$ cytoplasm with many mitochondria and dilated rough endoplasmic reticulum, with the presence of granular material of different electron densities (black arrows); IThe Golgi complex receives materials from transitional vesicles that are electron-lucid on the cis face (white arrow) and releases vesicles with granular electron-dense material on the trans face (black arrow). F fibroblast, FC follicular cell, G Golgi complex, L basal lamina, M mitochondria, N nucleus, NU nucleolus, RER rough endoplasmic reticulum 


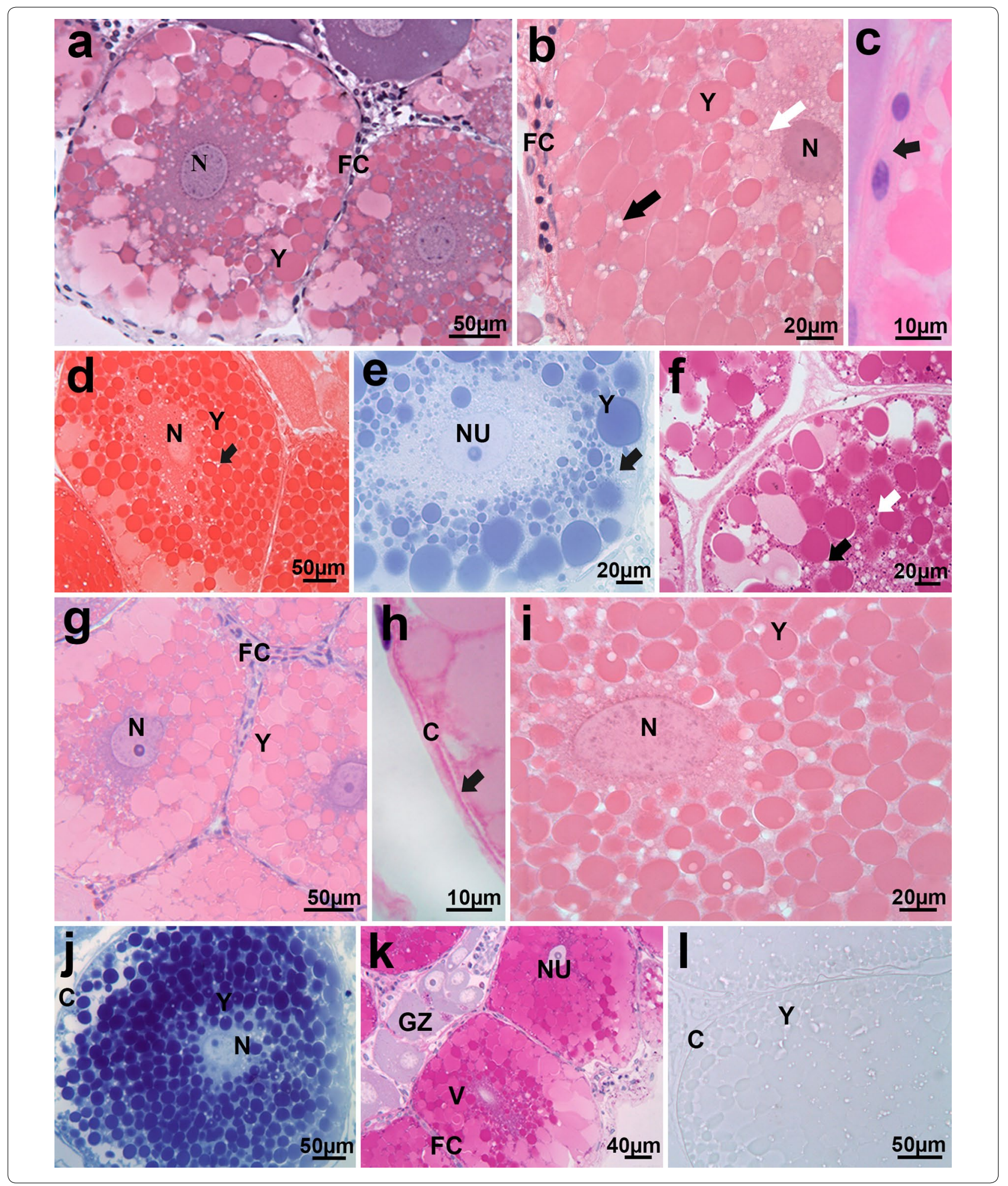




\section{(See figure on previous page)}

Fig. 3 Ovarian histology at the DE stage; a-c, $\mathbf{g}$-i stained with hematoxylin and eosin; $\mathbf{d}$ xylidine ponceau stain; $\mathbf{e , j}$ mercuric-bromophenol blue stain; f, k PAS stain; I Alcian blue stain; a Mithrax tortugae (Rathbun, 1920), oocyte with large central nucleus, surrounded by follicular cells showing mature yolk vesicles arranged in the oocyte cortex. b Mithrax hispidus (Herbst, 1790). Note the cytoplasmic vesicles in the perinuclear region (white arrow) and lucid vesicles between the yolk vesicles (black arrow); c Omalacantha bicornuta (Latreille, 1825), oocyte cortex without chorion (black arrow); d-f Mithrax hispidus, Mithrax tortugae and Mithraculus forceps A. Milne-Edwards, 1875, cytoplasm and yolk vesicles with positive reactivity for proteins and neutral polysaccharides; $\mathbf{g}$ Mithraculus forceps, more developed oocytes with perinuclear space filled by mature yolk vesicles; $\mathbf{h}$ Mithrax hispidus, oocyte cortex with thin chorion (black arrow); i Omalacantha bicornuta, rounded central nucleus; j, k Mithrax tortugae and Mithraculus forceps, cytoplasm and yolk vesicles with positive reactivity for proteins and neutral polysaccharides; I Mithrax hispidus, cytoplasm and yolk vesicles with the absence of acid polysaccharides. C chorion, FC follicular cell, GZ germinal zone, N nucleus, Nu nucleolus, Y yolk vesicle

as lucid vesicles under the light microscope (Fig. 3b). At this stage, $\mathrm{Y} 1$ appears to be in different compaction stages of the luminal content (Fig. 4c), and the vesicles do not have ribosomes attached to the membrane. $\mathrm{Y} 1$ receives small endocytic vesicles that merge with its membrane unit. Thus, the receipt of exogenous material from these vesicles will form Y2 (Fig. 4c, d). Y1 can also merge with each other, but we could not observe this type of fusion with Y2 (Fig. 4e). Y1 and Y2 are always surrounded by a single membrane unit (Fig. 4e, f). In the DE stage, we can observe the appearance of microvilli in the more developed oocytes, where the deposition of the chorion occurs (Fig. 4g). During this exogenous phase, the oolemma and its oocyte cortex show several endocytic vesicles. The newly formed endocytic vesicles are coated vesicles covered with a protein similar to clathrin (Fig. 4g, h).

In the MAT stage, the oocytes are the largest, with the cytoplasm completely filled with Y2 (Fig. 5a-d). The follicular cells maintain the form as simple squamous epithelium with flat nuclei. The chorion is acidophilic and a little thicker than that observed at the end of the DE stage, juxtaposed with the follicular cells (Fig. 5e). The chorion is extremely reactive to proteins and neutral polysaccharides (Fig. $5 \mathrm{f}-\mathrm{h}$ ), but in its glycoprotein constitution, there are no acid polysaccharides (Fig. 5i). Although it has a very variable structure, $\mathrm{Y} 2$ is larger compared to the previous stage, and when filling the cytoplasm, it is difficult to visualize the irregular and elliptical nuclei, which has a lower nucleus-cytoplasm volume in the mature oocytes (Fig. 5a-d, f). Y2 maintains the same glycoprotein composition with the same reaction intensity as observed in DE and remains negative for acid polysaccharides (Fig. 5f-i). Among Y2, there is an accumulation of intensely reactive PAS material, indicating the presence of glycogen (Fig. 5h). The ultrastructure of the MAT oocytes showed chorion maturation during this phase, modifying from a thick and irregular structure with the presence of microvilli in its interior to a perfectly regular structure with two layers of different electron densities at the end of the process (Fig. 6a, b). In the oocytes with irregular chorion, the endocytic vesicles are still observed as covered vesicles, but in a smaller number than that observed in previous stages (Fig. 6a, c). The follicular cells preserved the same structural aspect from the RUD, with the cytoplasm filled by RER and several mitochondria. The single difference observed is that the basal lamina of these cells is not as electron dense as that in the RUD stage (Figs. 2e, 6b). The cytoplasm of the oocytes is filled with Y2; however, among them, there are small areas with Y1, lipid droplets and $\alpha$ glycogen (Fig. 6d, e). Both Y1 and Y2 remain surrounded by a membrane unit (Fig. 6f).

The investment pattern in the oocyte growth varied among the species studied. Mithraculus forceps showed uniform growth between the stages with $83.96 \pm 26.65 \mu \mathrm{m}$ in the RUD, $248.33 \pm 45.99 \mu \mathrm{m}$ in the DE and $440.22 \pm 97.78 \mu \mathrm{m}$ in the MAT stage. Mithrax tortugae has the highest growth rate between the DE and MAT stages, ranging from $295.90 \pm 28.06$ to $551.70 \pm 48.44 \mu \mathrm{m}$. In M. hispidus, the highest investment in oocyte growth occurs between the RUD and DE stages, ranging from $159.28 \pm 23.52$ to $426.79 \pm 54.56 \mu \mathrm{m}$ and stabilizing between the DE and MAT stages (Table 1).

In the statistical analyses, the mean diameter of oocytes of $M$. tortugae and Mi.forceps showed a significant difference between the stages (RUD, DE and MAT) $(p<0.05$, KruskalWallis, Dunn method comparisons). In $M$. hispidus, there was no significant difference between the DE and MAT stages (Dunn $=1473, p<0.05$ ), indicating that, in these species, the nutrient incorporation rate is low in MAT, with the RUD and DE stages being the main yolk absorption phases.

\section{Discussion}

Although the monophyletism of some Majoidea families is still controversial [25-27], Mithracidae forms a monophyletic well-supported group [28 and references therein]. Because Mithracidae appears to be a cohesive group and the ovary development of the species studied here shows similar patterns in the macroscopic, histological, histochemical and ultrastructural characteristics in all developmental stages, we consider this pattern common to the family. A similar model of ovarian development under light microscopy was also observed in Chionoecetes opilio and Hyas coarctatus 


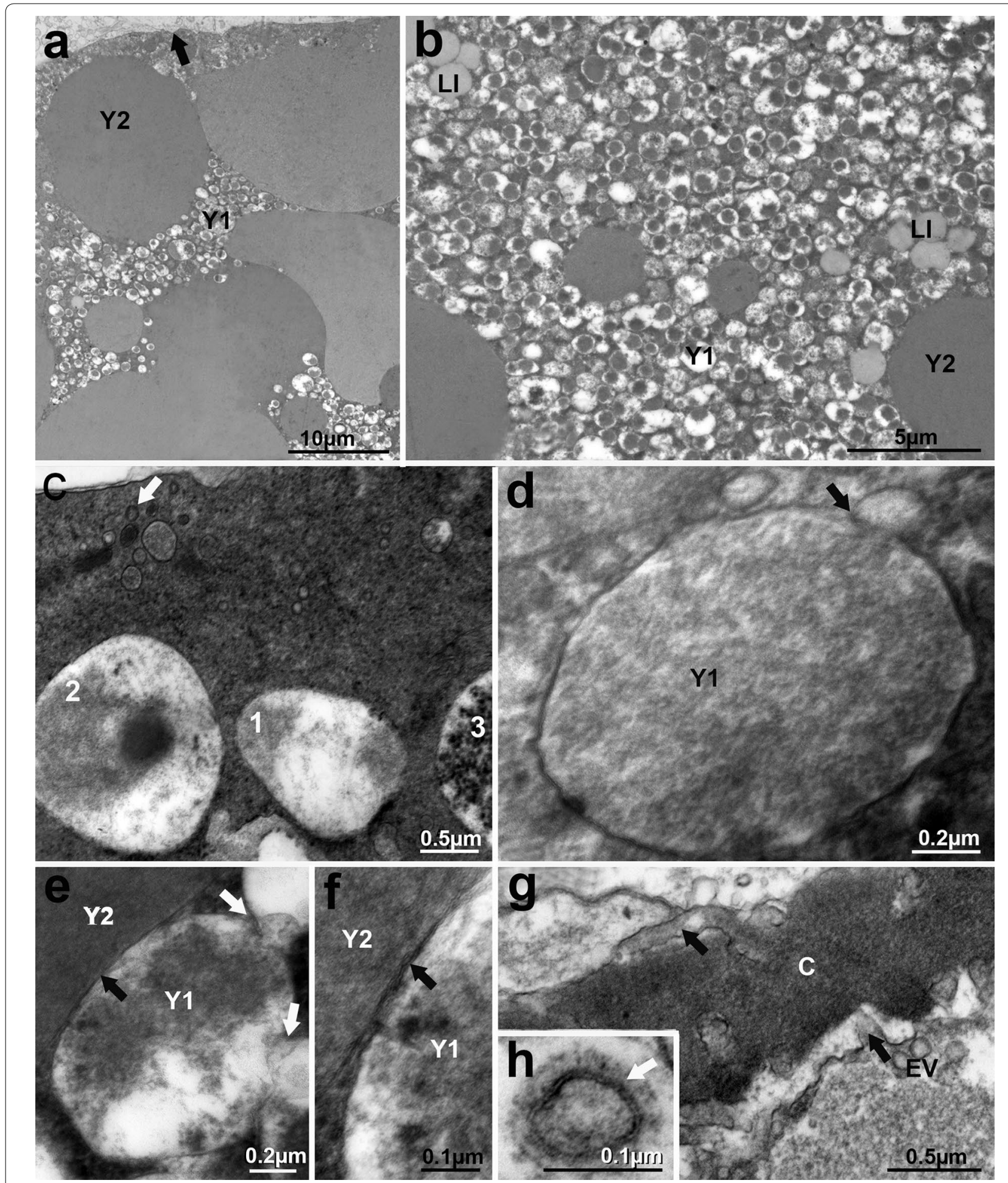

Fig. 4 Ovarian ultrastructure at the DE stage; $\mathbf{a}$, b oocyte cortex without chorion (black arrow). Cytoplasm filled with immature and mature yolk vesicles, with many lipid droplets; $\mathbf{c}$ different compaction stages of the endogenous yolk vesicles (1,2 and 3). Note the presence of endocytic vesicles in the oocyte cortex (white arrow); d endogenous yolk vesicles received small endocytic vesicles by fusion (black arrow). Notice the absence of ribosomes attached to the membrane; ef fusion between the endogenous yolk vesicles (white arrows). Immature and mature yolk vesicles surrounded by the membrane unit (black arrows); $\mathbf{g}$ Microvilli (black arrow) between the chorion and oocyte cortex showing endocytosis; $\mathbf{h}$ endocytic coated vesicle (white arrow). 1. Endogenous yolk vesicle with luminal material, 2. endogenous yolk vesicle with finely electron-dense material, 3. endogenous yolk vesicle with granular material, C chorion, EV endocytic vesicle, Ll lipid droplet, $Y 1$ immature yolk vesicles, $Y 2$ mature yolk vesicles 
and was considered by Lanteigne et al. [14] to be typical for the family Oregoniidae. Thus, phylogenetically close majoid species appear to have similar patterns of ovarian development.

The pattern of ovary maturation for Mithrax hispidus, M. tortugae, Mithraculus forceps and Omalacantha bicornuta is macroscopically divided into three stages: RUD, DE and MAT. However, in histological and ultrastructural analyses, we could identify four stages of development, as described for other Majoidea [6, 13, $14,16,29,30]$. In our macroscopic analyses, the four stages of development were not identified because of the variable relationship between the ovary and hepatopancreas. In the DE, we observed a higher increase in the yolk vesicles in the ovary; however, we could not identify macroscopically a proportion between the size of the ovary and the hepatopancreas as proposed for other groups, such as Portunidae [4, 7, 31, 32]. For instance, in Callinectes danae Smith, 1869 the differentiation between the DE and intermediary stage (INT) is characterized by the appearance of the chorion and an increasing size [7]. Although present in mithracids, the INT stage could only be determined by histology and TEM.

In the beginning of the RUD stage, the species have a large number of oogonia with large nuclei, nucleoli. The oocytes during development are enclosed by follicular cells, being this process similar to other Majoidea [16], Raninidae [33], Portunidae [7], Ocypodidae [34] and to Penaeidae [35] and Palaemonidae [36] shrimps. The central germinal zone facilitates the displacement of the oocytes to the ovarian margin during the development [37], which is apparently a pattern for Majoidea [14-16] and other Brachyura such Uca rapax (Smith, 1870), Callinectes ornatus Ordway, 1863 and C. danae [7, 34, 38]. According to the histochemical tests, oogonia and oocytes have basophilic cytoplasm composed of protein, neutral polysaccharides (glycogen) and the absence of acid polysaccharides in all phases of development as observed in Chionoecetes opilio and Hyas coarctatus [14]. Contrary to the Majoidea, the oocytes of other brachyuran groups, such as Cardisoma guanhumi Latreille, 1825 [39] and Callinectes danae [7], presented a positive reaction to acid polysaccharides in the initial phases of development.

In TEM, the RUD oocytes are characterized by endogenous vitellogenesis, and these cells are in preparation to start intense protein synthesis due to the large number of ribosomes, mitochondria, dilated RER and Golgi complexes as observed in Libinia emarginata [15]. Electron-dense granules or spherical nuages are found in large amounts in the perinuclear region, forming clusters of ribosomes. The same clusters were also found during the early stage in other phylogenetically distant species, such as the Malaysian prawn Macrobrachium rosenbergii de Man, 1879 [36]. In Mithracidae, the nuages are different from those observed in Maja brachydactyla [16]. At the beginning of primary vitellogenesis (endogenous phase), the nuages move from the nuclear envelope and settle in the central area of the cytoplasm, where they are associated with the mitochondrial masses forming the intermitochondrial cement [16]. We could not observe intermitochondrial cement formation in the studied species. Thus, the beginning of endogenous vitellogenesis is marked by the dilatations of the RER, which has granular material of different electron densities in the interior to form masses of endogenous luminal yolk. In L. emarginata, Y1 originates from the progressive differentiation of the RER [15]. In Ma. brachydactyla, the formation of Y1 starts with an internal regression of the mitochondria with the participation of autophagosomes becoming bright vesicles with granular material inside [16]. Although Rottlant et al. [16] do not exclude the participation of the RER in the synthesis of Y1, they directly assign the development of these vesicles to the mitochondria and Golgi complex. The intense participation of the Golgi complex in the synthesis of the electron-dense granular material, responsible for the origin of the yolk vesicles is common to all other known majoidean species $[15,16]$. Here, we only observed the vesicles leaving the Golgi complex and apparently returning to the dilated vesicles of the $\mathrm{Y} 1$ or even to the dilated endoplasmic reticulum (ER) without ribosomes. Thus, the Golgi complex receives material from the RER, modifies it and sends it to another cytoplasmic region, thus being a very active organelle at this stage of the ovarian development.

In DE and MAT, the oocytes are mostly filled by Y2. At the beginning of the $\mathrm{DE}, \mathrm{Y} 1$ receives exogenous material and progressively becomes $\mathrm{Y} 2$ composed of glycoproteins with neutral polysaccharides exclusively. The absence of acid polysaccharides was also reported for Callinectes danae, although it is poorly known in Brachyura [7]. Both phases have lipid droplets in the interior of the oocytes with the ovary being the only place where the lipids are segregated and incorporated in the development of the oocytes [14]. Despite the similarities, histological techniques showed differences in the quantity, distribution and size of the yolk vesicles in the interior of the oocyte and in the morphology of the follicular cells and production of the chorion, which is almost absent in the DE stage. Oocytes of the MAT stage have more compact amounts of $\mathrm{Y} 2$, hindering the visualization of the nuclei as also described for Portunidae [7]. The follicular cells are slender, and the chorion is slightly thicker, similar to what is observed in other brachyurans (e.g., [7, $16,38])$. 


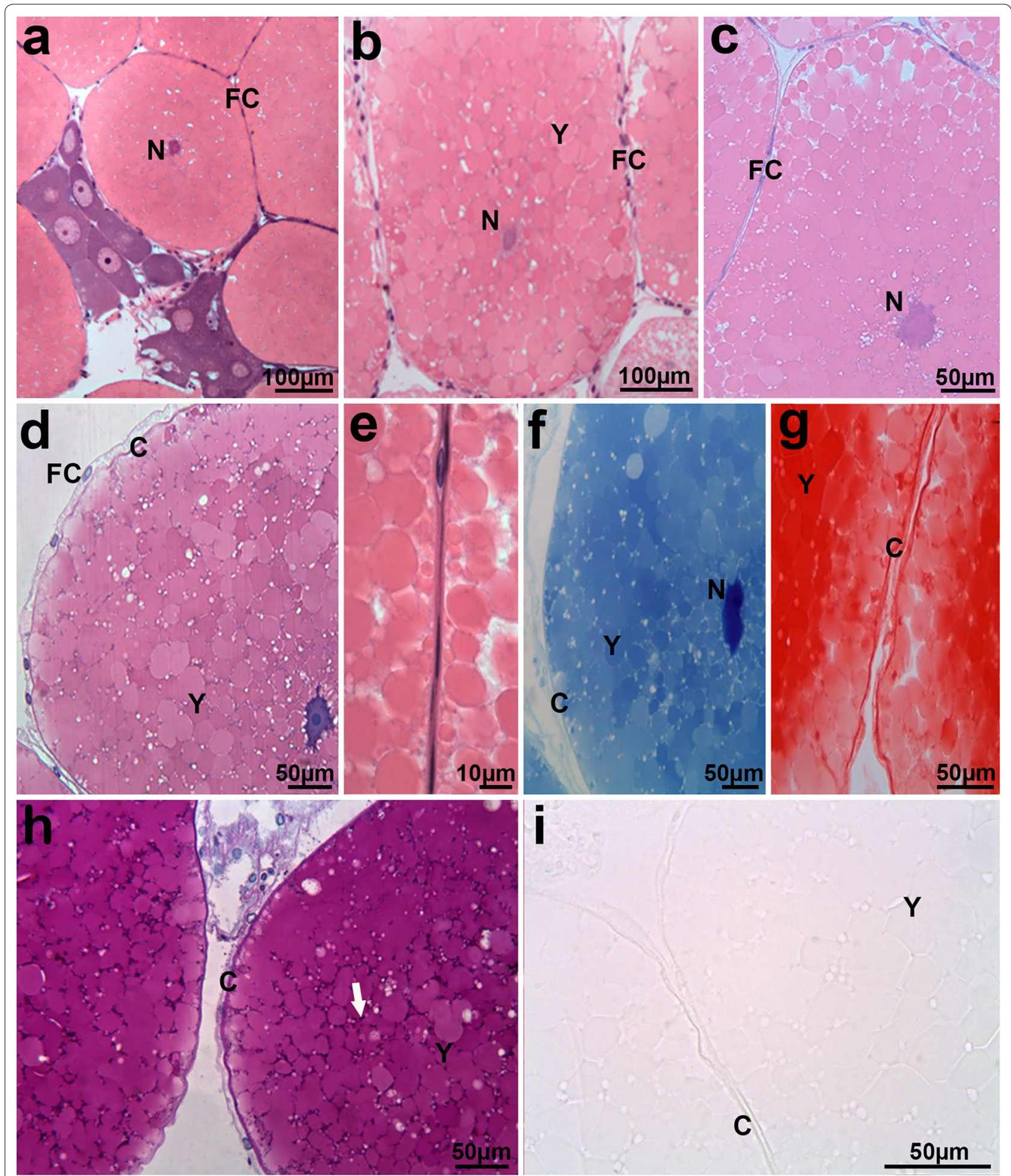

Fig. 5 Light microscopy of the MAT stage; a-e hematoxylin and eosin stain; $\mathbf{f}$ mercuric-bromophenol blue stain; $\mathbf{g}$ xylidine ponceau stain; $\mathbf{h}$ PAS stain; i Alcian blue stain; a-c Mithrax tortugae (Rathbun, 1920), Mithrax hispidus (Herbst, 1790) and Mithraculus forceps A. Milne-Edwards, 1875, oocyte showing irregular nucleus and cytoplasm filled with mature yolk vesicles. Note the elliptical and flattened follicular cells; $\mathbf{d}$, e Mithrax tortugae and Mithraculus forceps, acidophilic chorion juxtaposed follicular cells; $\mathbf{f}, \mathbf{g}$ Mithrax tortugae and Omalacantha bicornuta (Latreille, 1825), chorion and yolk vesicles reactive for proteins; $\mathbf{h}$ Mithrax tortugae, chorion and yolk vesicles reactive for neutral polysaccharides; $\mathbf{i}$ Omalacantha bicornuta chorion and yolk vesicles with the absence of acid polysaccharides. Note the glycogen granules (white arrow) among the yolk vesicles. C chorion, FC follicular cell, $N$ nucleus, $Y$ yolk vesicles 

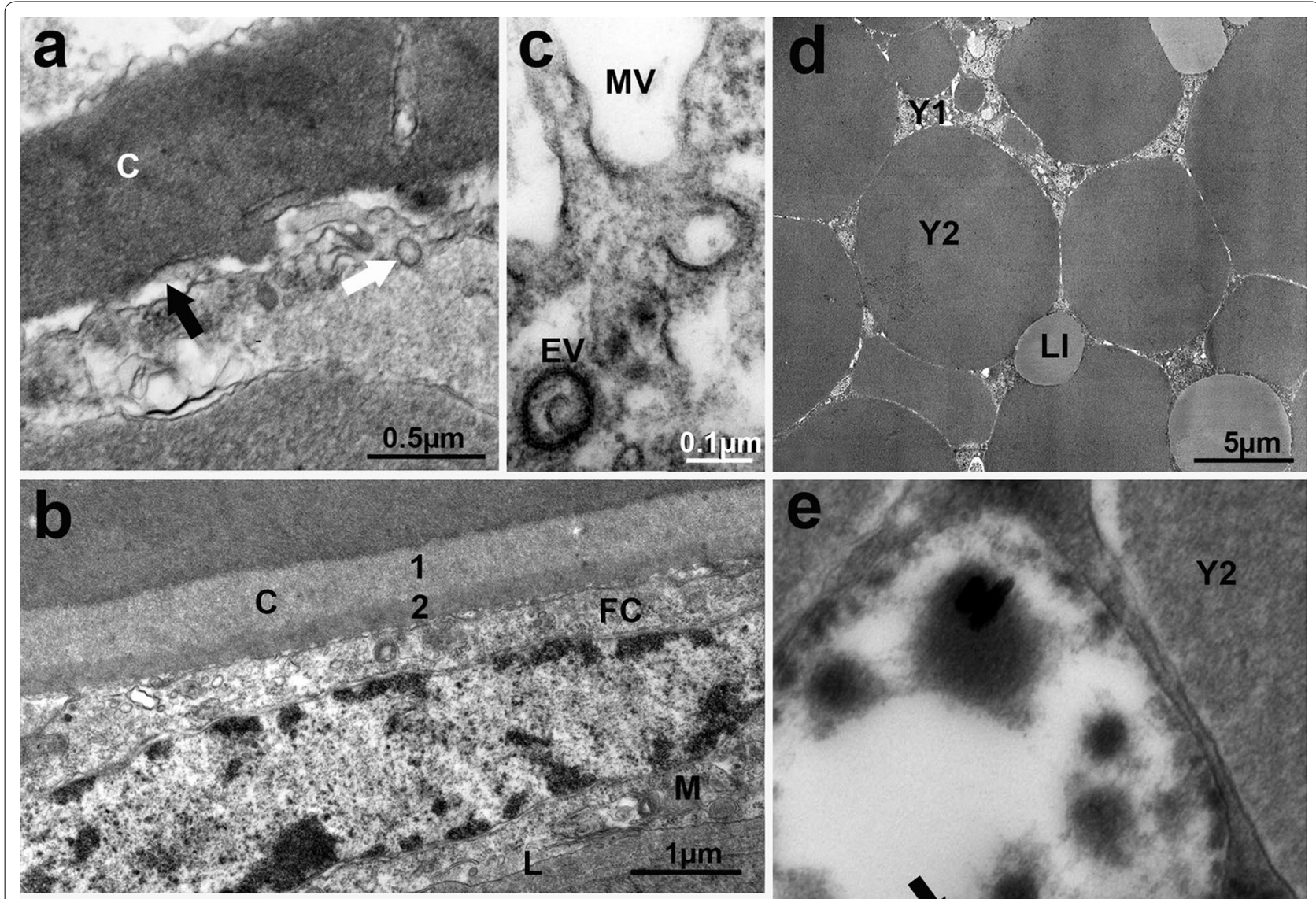

\section{(a)}
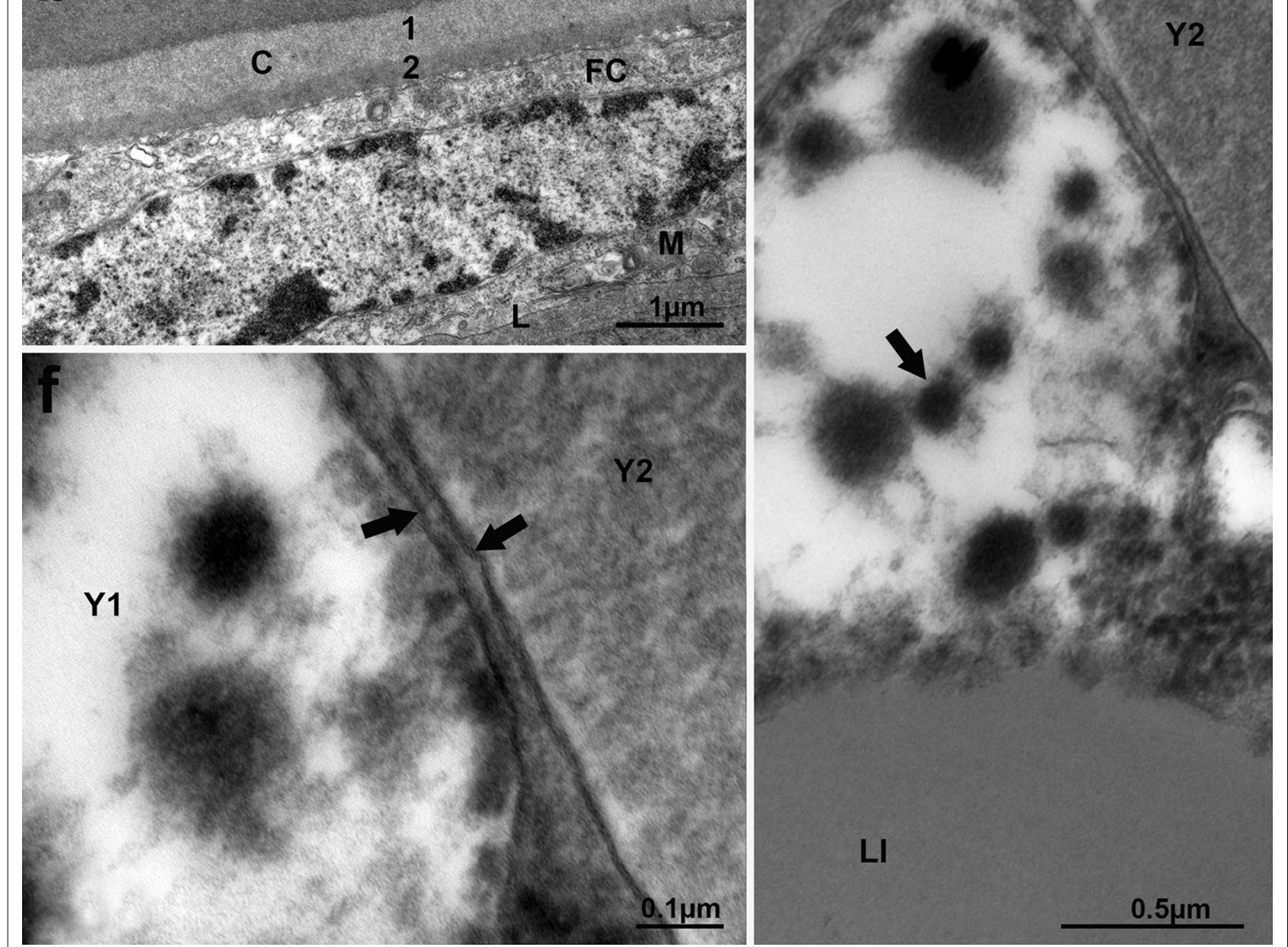

Fig. 6 Ovarian ultrastructure at the MAT stage of development; a thick and irregular chorion, still with the presence of microvilli (black arrow). Note some endocytic vesicles (white arrow); b regular chorion, with two layers of different electron-dense material (1 and 2). Follicular cell with less electron-dense basal lamina and cytoplasm with mitochondria; c endocytic-coated vesicle; $\mathbf{d}$, e cytoplasm filled with mature yolk vesicles, among them, small areas with immature yolk, lipid droplets and glycogen a (black arrow); $\mathbf{f}$ immature and mature yolk vesicles surrounded by the membrane unit (black arrows). 1. less electron-dense chorion layer, 2. more electron-dense chorion layer, C chorion, EV endocytic vesicle, FC follicular cell, L basal lamina, LI lipid, M mitochondria, MV microvilli, Y1 immature yolk vesicle, Y2 mature yolk vesicle 
Table 1 Larger diameter of the oocytes at each stage of development for the species studied

\begin{tabular}{lrll}
\hline Species & RUD $(\boldsymbol{\mu m})$ & DE $(\boldsymbol{\mu m})$ & MAT $(\boldsymbol{\mu m})$ \\
\hline Mithrax hispidus & $159.28 \pm 23.52$ & $426.79 \pm 54.56$ & $462.16 \pm 31.25$ \\
Mithrax tortugae & $142.17 \pm 44.68$ & $295.90 \pm 28.06$ & $551.70 \pm 48.44$ \\
Mithraculus forceps & $83.96 \pm 26.65$ & $248.33 \pm 45.99$ & $440.22 \pm 97.78$
\end{tabular}

Values are given as mean \pm standard deviation. $R U D$ rudimentary, $D E$ developing and $M A T$ mature stages of ovarian development

The beginning of exogenous vitellogenesis in the species studied occurs at the DE stage as seen in TEM. This process was categorized by the presence of coated vesicles on the oolemma and many cytoplasmic endocytic vesicles. Such vesicles are responsible for the extracellular uptake of different compounds, a characteristic of the exogenous vitellogenesis. At this stage, the oocytes have several microvilli and the oocyte cortex showing many signs of endocytosis, which is apparently a pattern for Majoidea [15, 16]. The same heterosynthetic process of the yolk vesicle formation can be observed in other invertebrate taxa, such as the polychaete Phragmatopoma caudata Krøyer in Mörch, 1863 [40], but it is absent in some crustacean such as the giant red shrimp Aristaeomorpha foliacea (Risso, 1827) [41]. After the beginning of exogenous vitellogenesis, endogenous vitellogenesis is still active but decreases gradually. At this point, we can observe both types of yolk vesicles in the cytoplasm, similar to that observed in L. emarginata and Ma. brachydactyla $[15,16]$. In all analyzed species the follicular cells maintained the same ultrastructural aspect from the RUD stage. However, in Ma. brachydactyla these cells became enlarged and the cytoplasm has the appearance of a secretory cell [16]. At the end of the DE stage, the development of oocyte microvilli with chorion deposition is fairly irregular. The oocyte cortex has several endocytic vesicles, and the oocytes are almost filled with Y2 corresponding to the INT stage.

The MAT stage has much fewer endocytic vesicles and less Y1, indicating the final stage of maturation of the ovary. The cell is almost completely filled with Y2 formed with compounds from the exogenous phase that were taken up from hemolymph during the DE stage, similar to that described for other Majoidea $[15,16]$. The chorion at this stage is more compact and thick, with two different layers of electron density, as observed in Libinia emarginata [42].

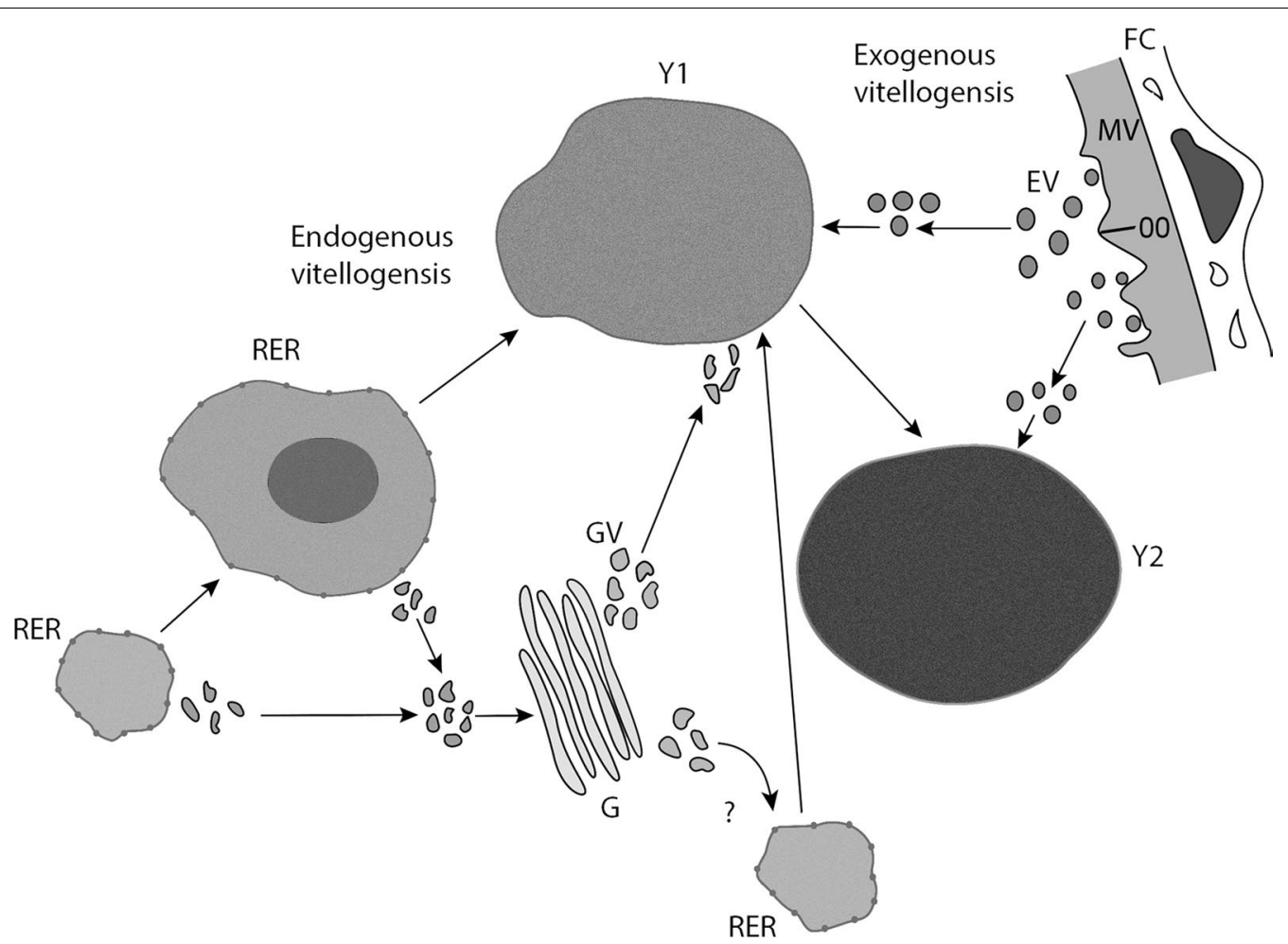

Fig. 7 Schematic diagram illustrating the process of yolk vesicle formation in Mithrax hispidus (Herbst, 1790), Mithrax tortugae (Rathbun, 1920), Mithraculus forceps A Milne-Edwards, 1875, and Omalacantha bicornuta (Latreille, 1825). ?. Uncertain return of the GV to the RER, EV endocytic vesicles, FC follicular cell, G Golgi complex, GV Golgi vesicles, MV microvilli, OO oolemma, RER rough endoplasmic reticulum, Y1 immature yolk vesicle, Y2 mature yolk vesicle 
We noticed a variation among the species studied in relation to the investment in the oocyte growth. In $M$. tortugae, the greatest increase in size was between the DE and MAT stages; however, in M. hispidus, the greater absorption of nutrients occurred between the RUD and DE stages. Mithraculus forceps shows a continuous growth rate among all stages. The accumulation of yolk during the phases of development is variable among the species studied here, although they have the same pattern of ovarian development, and occurs in two phases: endogenous and exogenous vitellogenesis. During endogenous vitellogenesis, the dilated RER receives electron-dense material and passes through a process of compaction and formation of the immature yolk with the Golgi complex, which is responsible for the synthesis of some of this material. The exogenous phase is characterized by the presence of the endocytic vesicles, which are responsible for capturing the extracellular compounds. These vesicles migrate to $\mathrm{Y} 1$ or $\mathrm{Y} 2$, increasing the size of the yolk vesicles. The summary of this synthesis is shown in Fig. 7.

\section{Conclusions}

The ovarian development pattern of the analyzed Mithracidae species showed many similarities to the previously described Majoidea species, such as the composition, arrangement and increment of the yolk vesicles during oocyte maturation. In relation to the vitellogenesis, the analyzed species have distinct ultrastructural characteristics from those previously described for majoids, such as the immature yolk formation without direct participation of the mitochondria characterizing the endogenous phase. Additionally the participation of the rough endoplasmic reticulum in the endogenous phase described here is a pattern more similar to that observed in Libinia (subfamily Pisinae) [15] than in Maja (family Majidae) [16], previous majoid groups in which ovarian development has been described. This work using Mithracidae as a model detailed the entire process of the ovarian development and can be useful in several contexts, such as characterizing groups in Majoidea and helping understand the evolution of female reproductive systems.

\begin{abstract}
Abbreviations
CW: carapace width; DE: developing; INT: intermediary; MAT: mature; PAS: Periodic Acid Schiff; ER: endoplasmic reticulum; RER: rough endoplasmic reticulum; RUD: rudimentary; TEM: transmission electron microscopy; Y1: immature or endogenous yolk vesicles; Y2: mature or exogenous yolk vesicles.
\end{abstract}

\section{Authors' contributions}

This study is part of the master's degree dissertation of MM, who conducted the analyses, interpreted the data and wrote the early drafts of the manuscript. FJZ and WS conceived the study, collected the samples, interpreted the data and wrote the manuscript. All authors read and approved the final manuscript.

\begin{abstract}
Author details
${ }^{1}$ Universidade do Sagrado Coração - USC, Pró-Reitoria de Pesquisa e PósGraduação, Rua Irmã Arminda, 10-50, Jd. Brazil, Bauru, SP 17011-160, Brazil.

${ }^{2}$ IML Invertebrate Morphology Laboratory, Department of Applied Biology, Aquaculture Center (CAUNESP), IEAMar-UNESP, Universidade Estadual Paulista (UNESP), Jaboticabal, SP 14884-900, Brazil.
\end{abstract}

\section{Acknowledgments}

We are thankful to Laira Lianos (UNESP_Botucatu) for the help during the execution of this work and to Jessica Colavite (UNESP_Botucatu) for the help during figure preparations. We also thank the Laboratório de Microscopia Eletrônica, UNESP_FCAV—Jaboticabal and Márcia Fiorese Mataqueiro (UNESP_FCAV—Jaboticabal) for laboratory support. This work greatly benefits from the comments of two anonymous reviewers.

\section{Competing interests}

The authors declare that they have no competing interests.

\section{Availability of data and materials}

The data supporting the conclusions of this article are available in the main paper.

\section{Consent for publication}

The authors declare that they consent to publish in this journal.

\section{Ethics approval and consent to participate}

Samples were collected in compliance with the Brazilian state and federal environmental laws (permanent license for collection of Zoological Material MMA/ICMBio/SISBIO number 37356-1 to WS and 34587-1 to FJZ). The manuscript has been approved by all authors.

\section{Funding}

This work received financial support from the São Paulo Research Foundation - FAPESP to FJZ (BIOTA Grant \#2010/50188-8 and 2016/25344-2) and to WS (BIOTA Grant \#2013/01201-0) and from the National Counsel of Technological and Scientific Development - CNPq to FJZ (Universal \#486337/2013-8) and to WS (Universal \#429334/2016-8). The Coordenação de Aperfeiçoamento de Pessoal de Nível Superior - CAPES provided the fellowship received by MM and the financial support to FJZ (CIMAR II\# 1989/2014).

\section{Publisher's Note}

Springer Nature remains neutral with regard to jurisdictional claims in published maps and institutional affiliations.

Received: 6 February 2017 Accepted: 10 July 2017

Published online: 21 July 2017

\section{References}

1. Quintero MES, Garcia A. Stages of gonadal development in the spotted pink shrimp Penaeus brasiliensis. J Crustacean Biol. 1998;18:680-5. doi:10.2307/1549143.

2. Hartnoll RG. Mating in the Brachyura. Crustaceana. 1969;16:161-81. doi:1 $0.1163 / 156854069 \times 00420$.

3. Sal Moyano MP, Gavio MA, Cuartas El. Morphology and function of the reproductive tract of the spider crab Libinia spinosa (Crustacea, Brachyura, Majoidea): pattern of sperm storage. Helgol Mar Res. 2010;64:213-21. doi:10.1007/s10152-009-0180-9.

4. Costa TM, Negreiros-Fransozo ML. The reproductive cycle of Callinectes danae Smith, 1869 (Decapoda, Portunidae) in the Ubatuba region, Brazil. Crustaceana. 1998;71:615-27. doi:10.1163/156854098X00617.

5. Reigada ALD, Negreiros-Fransozo ML. Reprodutive cycle of Hepatus pudibundus (Herbst, 1758) (Crustacea, Decapoda, Calappidae) in Ubatuba, SP, Brazil. Rev Bras Biol. 2000;60:483-91. doi:10.1590/ S0034-71082000000300013.

6. Sal-Moyano MP, Gavio MA, Maggi MD. Morphometric and gonad maturity of the spider crab Libinia spinosa (Crustacea: Brachyura: Majoidea: Epialtidae) in Argentina. J. Mar Biol Assoc. 2011;91:837-44. doi:10.1017/ S0025315410001657. 
7. Zara FJ, Gaeta HH, Costa TM, Toyama MH, Caetano FH. The ovarian cycle histochemistry and its relationship with hepatopancreas weight in the blue crab Callinectes danae (Crustacea: Portunidae). Acta Zool. 2013;94:134-46. doi:10.1111/j.1463-6395.2011.00537.x.

8. Davie PJF, Guinot D, Ng PKL. Systematics and classification of Brachyura. In: Castro P, Davie PJF, Guinot D, Schram FR, Vaupel Klein JC, editors. Treatise on zoology-anatomy, taxonomy, biology. The Crustacea. Volume 9C-II. Decapoda: Brachyura (Part 2). Boston: Brill Leiden; 2015. p. 1049-130.

9. Rhyne AL, Penha-Lopes G, Lin J. Growth, development, and survival of larval Mithraculus sculptus (Lamark) and Mithraculus forceps (A. Milne Edwards) (Decapoda: Brachyura: Majidae): economically important marine ornamental crabs. Aquaculture. 2005;245: 83-191. doi:10.1016/j. aquaculture.2004.11.016.

10. Baeza JA, Bolaños JÁ, Fuentes S, Hernandez JE, Lira C, López R. Molecular phylogeny of enigmatic Caribbean spider crabs from the Mithrax-Mithraculus species complex (Brachyura: Majidae: Mithracinae): ecological diversity and a formal test of genera monophyly. J Mar Biol Assoc U K. 2010;90:851-8. doi:10.1017/S0025315409991044.

11. Abelló P, Guerao G, Salmerón F, Raso JEG. Maja brachydactyla (Brachyura: Majidae) in the western Mediterranean. Mar Biodivers Rec. 2014;7:1-5 doi:10.1017/S1755267214000827.

12. Melo GAS. Manual de identificação dos Brachyura (caranguejos e siris) do litoral brasileiro. São Paulo: Plêiade; 1996.

13. González-Gurriarán E, Fernández L, Freire J, Muiño R, Parapar J. Reproduction of the spider crab Maja squinado (Brachyura: Majidae) in the Southern Galician Coast (NW Spain). ICES J Mar Sci. 1993;19:1-15.

14. Lanteigne $C$, Beninger $P G$, Gionet $C$. Ontogeny of female primary sexual characters in the Majid crabs Chionoecetes opilio and Hyas coarctatus. J Crust Biol. 1996;6:501-14. doi:10.2307/1548740.

15. Hinsch GW, Cone VM. Ultrastructural observations of vitellogenesis in the spider crab. Libinia emarginata L. J. Cell Biol. 1969;40:336-42. doi:10.1083/ jcb.40.2.336.

16. Rotllant G, González-Gurriarán E, Fernández L, Benhalima K, Ribes E. Ovarian maturation of the multi-spawning spider crab Maja brachydactyla (Decapoda: Majidae) with special reference to yolk formation. Mar Biol. 2007;152:383-94. doi:10.1007/s00227-007-0688-y.

17. Williams AB. Shrimps, lobsters and crabs of Atlantic coast of the eastern United States, Maine to Florida. Washington: Smithsonian Institution Press; 1984

18. Wagner HP. The genera Mithrax Latreille, 1818 and Mithraculus White, 1847 (Crustacea: Brachyura: Majidae) in the western Atlantic Ocean. Zool Verh. 1990;265:1-65.

19. López-Greco LS, Lopez GC, Rodríguez EM. Morphology of spermathecae in the estuarine crab Chasmagnathus granulata Dana 1851 (Grapsidae, Sesarminae). J. Zool. 1999;249:490-93. doi:10.1111/j.1469-7998.1999. tb01222.x.

20. Junqueira LCU, Junqueira LMMS. Técnicas básicas de citologia e histologia. São Paulo: Santos; 1983

21. Sant'Anna BS, Turra A, Zara FJ. Simultaneous activity of male and female gonads in intersex hermit crabs. Aquatic Biol. 2010;10:201-9. doi:10.3354/ ab00283.

22. Pearse AGE. Histochemistry: theorical and applied. London: J\&A Churchill; 1960.

23. Gabe M. Histological techniques. New York: Springer; 1976.

24. Mello MSL, Vidal BC. Práticas de Biologia Celular. São Paulo: Edgar Blucher - FUNCAMP; 1980

25. Hultgren KM, Stachowicz JJ. Molecular phylogeny of the brachyuran crab superfamily Majoidea indicates close congruence with trees based on larval morphology. Mol. Phylogenet. Evol. 2008;48(3):986-96. doi:10.1016/j.ympev.2008.05.004.

26. Hultgren KM, Guerao G, Marques FPL, Palero FP. Assessing the contribution of molecular and larval morphological characters in a combined phylogenetic analysis of the superfamily Majoidea. In: Martin JW, Crandall KA, Felder DL, editors. Decapod crustacean phylogenetics. Crustacean issues. Koenemann, S. (series ed.). Volume 18. Boca Raton, London, New York: CRC Press, Taylor \& Francis Group; 2009. p. 437-55. doi: 10.1201/9781420092592-c22.

27. Ng PKL, Guinot D, Davie PJF. Systema Brachyurorum: part I . An annotaded checklist of extant brachyuran crabs of the world. Raffles Bull Zool. 2008;17:1-286.
28. Windsor AM, Felder DL. Molecular phylogenetics and taxonomic reanalysis of the family Mithracidae MacLeay, 1838 (Decapoda: Brachyura: Majoidea). Invertebr Syst. 2014;28:124-44. doi:10.1071/IS13011.

29. Carmona-Suarez CA. Reproductive biology and relative growth in the spider crab Maja crispata (Crustacea: Brachyura: Majidae). Sci Mar. 2003;67:75-80. doi:10.3989/scimar.2003.67n175.

30. Mura M, Orrù F, Cau A. Size at sexual maturity of the spider crab Anamathia rissoana (Decapoda: Majoidea) from the Sardinian Sea. J Crustacean Biol. 2005;25:110-5. doi:10.1651/C-2520.

31. Mantelatto FLM, Fransozo A. Reproductive biology and moulting cycle of the crab Callinectes ornatus (Decapoda, Portunidae) from the Ubatuba region, São Paulo, Brazil. Crustaceana. 1999;72:63-76. doi:10.1163/156854099502871.

32. Pinheiro MAA, Fransozo A. Sexual maturity of the speckled swimming crab Arenaeus cribrarius (Lamarck, 1818) (Decapoda, Brachyura, Portunidae), in the Ubatuba littoral, São Paulo state, Brazil. Crustaceana. 1998;71:434-52. doi:10.1163/156854098X00536.

33. Minagawa M, Chiu RJ, Kudo M, Ito F, Takashima F. Female reproductive biology and oocyte development of the red frog crab, Ranina ranina, off Hachijojima, Izu Islands. Japan. Mar Biol. 1993;115:613-23. doi:10.1007/ BF00349369.

34. Castiglioni DS, Negreiros-Fransozo ML, López Greco LS, Silveira AF, Silveira SO. Gonad development in females of fiddler crab Uca rapax (Crustacea, Brachyura, Ocypodidae) using macro and microscopic techniques. Iheringia, Sér Zool. 2007;97:505-10. doi:10.1590/S0073-47212007000400022.

35. Campos BR, Dumont LLC, D'Incao F, Branco JO. Ovarian development and length at first maturity of the sea-bob-shrimp Xiphopenaeus kroyeri (Heller) based on histological analysis. Nauplius. 2009;17:9-12.

36. Soonklang NW, Wanichanon C, Stewart MJ, Stewart P, Meeratana P, Hanna PJ, Sobhon P. Ultrastructure of differentiating oocytes and vitellogenesis in the giant freshwater prawn, Macrobrachium rosenbergii (de Man). Microsc Res Techniq. 2012;75:1402-15. doi:10.1002/jemt.22081.

37. Adiyodi RG, Subramonian T. Arthropoda-Crustacea. In: Adiyodi KG, Adiyodi RG, editors. Reproductive biology of invertebrates, vol. 1, Oogenesis, oviposition and oosorption. New York: Wiley; 1983. p. 443-95.

38. Keunecke KA, Silva DR, Vianna M, Verani JR, D'Incão F. Ovarian development stages of Callinectes danae and Callinectes ornatus (Brachyura, Portunidae). Crustaceana. 2009;82:753-61. doi:10.1163/156854009X423175.

39. Shinozaki-Mendes RA, Silva JRF, Sousa LP, Hazin FHV. Histochemical study of the ovarian development of the blue land crab Cardisoma guanhumi (Crustacea: Gecarcinidae). Invertebr Reprod Dev. 2012;56:191-9. doi:10.10 80/07924259.2011.587277.

40. Faroni-Perez L, Zara FJ. Oogenesis in Phragmatopoma (Polychaeta: Sabellariidae): evidence for morphological distinction among geographically remote populations. Mem Mus Vic. 2014;71:53-65.

41. Desantis S, Labate M, Maiorano P, Tursi A, Labate GM, Ciccarelli M. A histochemical and ultrastructural study of oogenesis in Aristaeomorpha foliacea (Risso, 1827). Hydrobiologia. 2001;449:253-9. doi:10.1007/978-94-017-0645-2_28.

42. Hinsch GW. Penetration of the oocyte envelope by spermatozoa in the spider crab. J Ultrastruct Res. 1971;35:86-97. doi:10.1016/ S0022-5320(71),80144-2.

\section{Submit your next manuscript to BioMed Central and we will help you at every step:}

- We accept pre-submission inquiries

- Our selector tool helps you to find the most relevant journal

- We provide round the clock customer support

- Convenient online submission

- Thorough peer review

- Inclusion in PubMed and all major indexing services

- Maximum visibility for your research

Submit your manuscript at www.biomedcentral.com/submit 